\title{
No drains in thoracic surgery with ERAS program
}

\author{
Cheng Shen and Guowei Che
}

\begin{abstract}
Enhanced recovery after lobectomy surgery (ERAS) concept has been greatly developed between clinical implementation and minimally invasive surgery. In addition to the minimally invasive surgery, the management of the perioperative catheter has also attracted everyone's attention. Tubeless minimally invasive treatment includes no urinary catheter placement during the operation and no chest tube after the operation. Here, we summarized all the reports on no urinary catheterization and no chest tube in patients with thoracic surgery and the impact of postoperative length of stay (LOS) and postoperative complications. We find that avoiding chest drain and urinary catheter placement after the surgery appears to be safe and beneficial for patients.
\end{abstract}

Keywords: Enhanced recovery after surgery, Bladder catheterization, Chest tube

\section{Background}

VATS is currently the common method of lobectomy or wedge resection for thoracic surgeons. At the same time, minimally invasive surgery is one of the main means of enhanced recovery after surgery (ERAS) [1-3]. Through the cooperation with multi-disciplinary departments, the ERAS concept has been greatly developed between clinical implementation and minimally invasive surgery. Tubeless minimally invasive treatment includes no urinary catheter placement during the operation and no chest tube after the operation. Here, we summarized all the reports on no urinary catheterization and no chest tube in patients with thoracic surgery and the impact of postoperative length of stay (LOS) and postoperative complications.

\section{Main text}

In addition to the minimally invasive surgery, the management of the perioperative catheter has also attracted everyone's attention [4]. Traditionally, bladder catheterization and chest tube are a routine procedure

\footnotetext{
* Correspondence: cheguowei_hx@aliyun.com

Department of Thoracic Surgery, West-China Hospital, Sichuan University, Chengdu 610041, China
}

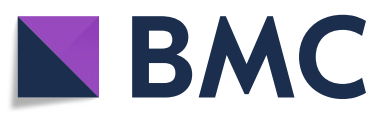

in treatment after general anesthesia in patients with thoracic surgery. If the patient removes the bladder catheterization early after the operation, it may lead to postoperative anesthesia dysuria. It is recommended to indwell the catheter after surgery for several days. However, the clinical drawbacks of this method are also obvious: Firstly, the patient's comfortability is significantly reduced, especially the Catheter-Related Bladder Discomfort (CRBD) in patients undergoing a urinary catheter insertion intraoperatively; secondly, the patient's activity is limited, which is not conducive to leave bed early and rapid recovery; thirdly, it will increase the occurrence of postoperative urinary retention (POUR) [5]. Recently, some clinically relevant studies have shown that performing a certain fluid management during surgery can control the amount of urine, and inserting a catheter to monitor perioperative urine volume may not be an essential operation during the perioperative period. No urinary catheter placement during the operation is one of the core elements of tubeless minimally invasive treatment $[4,6]$.

The placement of chest tube after surgery will increase the feeling of chest pain and rise the amount of analgesic used in patient, even extend the length of hospital stay

(c) The Author(s). 2020 Open Access This article is licensed under a Creative Commons Attribution 4.0 International License, which permits use, sharing, adaptation, distribution and reproduction in any medium or format, as long as you give appropriate credit to the original author(s) and the source, provide a link to the Creative Commons licence, and indicate if changes were made. The images or other third party material in this article are included in the article's Creative Commons licence, unless indicated otherwise in a credit line to the material. If material is not included in the article's Creative Commons licence and your intended use is not permitted by statutory regulation or exceeds the permitted use, you will need to obtain permission directly from the copyright holder. To view a copy of this licence, visit http://creativecommons.org/licenses/by/4.0/ The Creative Commons Public Domain Dedication waiver (http://creativecommons.org/publicdomain/zero/1.0/) applies to the data made available in this article, unless otherwise stated in a credit line to the data. 
(LOS) [4]. More importantly, it will affect the early activity of patient after surgery. Although it has been reported that surgeons attempt to shorten the time of postoperative chest tube drainage by controlling the occurrence of postoperative complications, the guidelines for the operation of thoracic surgery do not suggest omitting the placement of chest tube after the surgery [7]. Combined with a small number of published studies, early chest extraction or no chest tube have better perioperative outcomes in patients compared with conventional $28 \mathrm{~F}$ chest tube placement. Based on cases of nonintubated VATS group comparing to general chest tube group, Cui et al [8] found that a significantly decreased postoperative pleural drainage volume could be expected in tubeless patients and they found significantly decreased inflammatory cytokine levels in the lung and decreased lung infection in comparison to the results for the bronchoalveolar lavage fluid and serum inflammatory cytokines. All these modalities can make thoracic day surgery a reality.

So we searched all of the articles that were published from October 2000 to February 2020 in the PubMed, Web of Science, EMBASE and CNKI databases and only several researches were involved in the present study. Here, we summarized all the reports on no urinary catheterization and no chest tube in patients with thoracic surgery and the impact of postoperative length of stay (LOS) and postoperative complications (Tables 1 and 2). The guideline of Newcastle-Ottawa Scale (NOS) was used for evaluating this research including three perspectives of selection, comparability and exposure. The assessment tool including the star system, a maximum of 9 stars, was used in this research. Specific evaluation system is that 8-9 stars are high quality; 6-7 stars are reasonable quality, and 6 stars or less are bad.

The key point of ERAS emphasizes the optimization management of perioperative procedures. The clinical focus is on optimizing patient care processes such as shortening the time of examination and tubeless. The reducing postoperative complications and shortening LOS as a criterion for evaluating the feasibility of the ERAS program by most of clinical surgeons [21].

As seen in our Table 1, two researchers mentioned the relationship between operation time and urinary catheterization. Lai et al [5] and Qiu et al [10] reported that there was no significant statistical difference between indwelling catheter and operation time. In the time of postoperative LOS, it showed that there was a statistically significant difference between the NUC group and the UC group, especially in the Li et al's report [4], 34 patients with small pulmonary nodules were treated using VATS and no urinary catheter during the operation with only one postoperative day. For patients undergoing VATS thoracic surgery, no urinary catheter during the operation was associated with significantly shorter hospital stay.

POUR is clinically defined as acute urinary retention is one of the common complications after the surgery. To develop an enhanced recovery pathway to improve efficiency, shortening LOS is important in terms of quality of patient care, but also healthcare costs. The diagnosis of POUR has clinical implications such as delayed discharge, prolonged LOS, potential risk of systemic infection from urinary catheterization and possible long-term bladder dysfunction [5]. In addition, the results of the 2019 study showed that the incidence of UTI in NUC group was significantly lower than in UC group. In the

Table 1 Summary of articles reporting on no urinary catheterization in patients with thoracic surgery

\begin{tabular}{|c|c|c|c|c|c|c|c|c|c|c|c|c|c|c|}
\hline \multirow[t]{2}{*}{ Author } & \multirow[t]{2}{*}{ YOP } & \multirow{2}{*}{$\begin{array}{l}\text { Study } \\
\text { Period }\end{array}$} & \multirow[t]{2}{*}{ Study Type } & \multirow[t]{2}{*}{ TP } & \multirow[t]{2}{*}{ NUCP } & \multirow[t]{2}{*}{ UCP } & \multicolumn{4}{|c|}{ NUC Group } & \multicolumn{4}{|l|}{ UC Group } \\
\hline & & & & & & & $\begin{array}{l}\text { OT } \\
(\mathrm{min})\end{array}$ & $\begin{array}{l}\text { P-LOS } \\
\text { (day) }\end{array}$ & UR & UTI & OT (min) & $\begin{array}{l}\text { P-LOS } \\
\text { (day) }\end{array}$ & UR & UTI \\
\hline Lai [5] & 2019 & 2014-2017 & $\begin{array}{l}\text { Retrospective: } \\
\text { cohort study }\end{array}$ & 2495 & 660 & 1835 & 115 & 4 & $\begin{array}{l}74 \\
(11.2 \%)\end{array}$ & $\begin{array}{l}38 \\
(5.7 \%)\end{array}$ & 120 & 5 & $\begin{array}{l}136 \\
(7.4 \%)\end{array}$ & $\begin{array}{l}153 \\
(8.3 \%)\end{array}$ \\
\hline $\begin{array}{l}\text { Peng } \\
{[6]}\end{array}$ & 2017 & 2014-2015 & $\begin{array}{l}\text { Retrospective: case } \\
\text { series }\end{array}$ & 43 & 40 & - & $22 \pm 5$ & - & $0(0 \%)$ & $0(0 \%)$ & - & - & - & - \\
\hline Li [4] & 2017 & 2012-2014 & $\begin{array}{l}\text { Retrospective: case } \\
\text { series }\end{array}$ & 34 & 34 & - & $42 \pm 10$ & $1 \pm 1$ & $0(0 \%)$ & $0(0 \%)$ & - & - & - & - \\
\hline $\begin{array}{l}\text { Yang } \\
{[9]}\end{array}$ & 2016 & 2015-2016 & $\begin{array}{l}\text { Retrospective: } \\
\text { cohort study }\end{array}$ & 148 & 74 & 74 & - & $4.4 \pm 1.0$ & - & - & - & $6.1 \pm 2.0$ & - & - \\
\hline $\begin{array}{l}\text { Qiu } \\
{[10]}\end{array}$ & 2016 & 2015-2016 & $\begin{array}{l}\text { Retrospective: } \\
\text { cohort study }\end{array}$ & 148 & 74 & 74 & $\begin{array}{l}96.7 \pm \\
30.4\end{array}$ & $4.0 \pm 1.1$ & $\begin{array}{l}5 \\
(6.7 \%)\end{array}$ & $\begin{array}{l}1 \\
(1.3 \%)\end{array}$ & $\begin{array}{l}107.2 \pm \\
28.4\end{array}$ & $6.2 \pm 1.0$ & $\begin{array}{l}7 \\
(9.4 \%)\end{array}$ & $\begin{array}{l}3 \\
(4.0 \%)\end{array}$ \\
\hline $\begin{array}{l}\mathrm{Xu} \\
{[11]}\end{array}$ & 2016 & 2014-2015 & $\begin{array}{l}\text { Prospective cohort } \\
\text { study }\end{array}$ & 133 & 65 & 68 & - & $5.0 \pm 1.6$ & $\begin{array}{l}3 \\
(4.6 \%)\end{array}$ & $\begin{array}{l}6 \\
(9.2 \%)\end{array}$ & - & $6.5 \pm 3.1$ & $\begin{array}{l}7 \\
(10.2 \%)\end{array}$ & $\begin{array}{l}18 \\
(26.4 \%)\end{array}$ \\
\hline $\begin{array}{l}\text { Qiu } \\
{[12]}\end{array}$ & 2015 & $\begin{array}{l}2014.4- \\
2014.12\end{array}$ & $\begin{array}{l}\text { Prospective cohort } \\
\text { study }\end{array}$ & 100 & 50 & 50 & - & $5.0 \pm 1.5$ & $\begin{array}{l}2 \\
(4.0 \%)\end{array}$ & $\begin{array}{l}6 \\
(12.0 \%)\end{array}$ & - & - & $\begin{array}{l}5 \\
(10.0 \%)\end{array}$ & $\begin{array}{l}18 \\
(36.0 \%)\end{array}$ \\
\hline
\end{tabular}

YOP year of publication, $T P$ total patients, NUCP non-urinary catheter patients, UCP urinary catheter patients, $O T$ operative time, $P$-LOS postoperative length of stay UR urinary retention, UTI urinary tract infection 
Table 2 Summary of articles reporting on no chest tube in patients with thoracic surgery

\begin{tabular}{|c|c|c|c|c|c|c|c|c|c|c|c|c|c|}
\hline \multirow[t]{2}{*}{ Author } & \multirow[t]{2}{*}{ YOP } & \multirow{2}{*}{$\begin{array}{l}\text { Study } \\
\text { Period }\end{array}$} & \multirow[t]{2}{*}{ TP } & \multirow[t]{2}{*}{$\mathrm{NCT}$} & \multirow[t]{2}{*}{$C T$} & \multicolumn{8}{|c|}{ NCT Group } \\
\hline & & & & & & OT & $\begin{array}{l}\mathrm{BL} \\
(\mathrm{mL})\end{array}$ & $\mathrm{OM}$ & LOS & $\mathrm{PN}$ & SE & PT & AT \\
\hline Cheng [13] & 2019 & $\begin{array}{l}2014- \\
2018\end{array}$ & 282 & 246 & 36 & $48 \pm 6$ & $3 \pm 0.4$ & VATS & 2 & - & $\begin{array}{l}202 \\
(82.11 \%)\end{array}$ & $2(0.8 \%)$ & - \\
\hline Watanabe [14] & 2017 & $\begin{array}{l}1998- \\
2002\end{array}$ & 93 & 42 & 34 & - & - & VATS WR & $\begin{array}{l}3.2 \pm \\
1.0\end{array}$ & - & - & $2(4.7 \%)$ & - \\
\hline Murakami [15] & 2017 & $\begin{array}{l}2012- \\
2014\end{array}$ & 162 & 102 & 60 & - & - & VATS & $\begin{array}{l}9.7 \pm \\
3.8\end{array}$ & $\begin{array}{l}3 \\
(1.8 \%)\end{array}$ & - & - & $\begin{array}{l}5 \\
(3.0 \%)\end{array}$ \\
\hline $\begin{array}{l}\text { Steunenberg } \\
{[16]}\end{array}$ & 2017 & $\begin{array}{l}2011- \\
2014\end{array}$ & 49 & 28 & 21 & - & - & VATS WR & 3 & $\begin{array}{l}1 \\
(3.5 \%)\end{array}$ & - & $2(7.1 \%)$ & - \\
\hline Lu [17] & 2016 & $\begin{array}{l}2013- \\
2015\end{array}$ & 89 & 44 & 45 & - & - & VATS WR & $\begin{array}{l}3.1 \pm \\
0.9\end{array}$ & - & $15(16.8 \%)$ & $0(0 \%)$ & - \\
\hline Yang [7] & 2016 & $\begin{array}{l}2015- \\
2016\end{array}$ & 60 & 30 & 60 & $72 \pm 21$ & - & $\begin{array}{l}\text { Uniportal VATS } \\
\text { WR }\end{array}$ & $\begin{array}{l}3.1 \pm \\
0.7\end{array}$ & - & $2(6.6 \%)$ & - & - \\
\hline Holbek [18] & 2016 & 2015 & 166 & 51 & 0 & 36 & - & VATS WR & 1 & - & $2(1.2 \%)$ & - & - \\
\hline Cui [8] & 2016 & $\begin{array}{l}2012- \\
2016\end{array}$ & 173 & 21 & 19 & $37 \pm 11$ & $\begin{array}{l}20.8 \pm \\
15.7\end{array}$ & VATS & $\begin{array}{l}1.5 \pm \\
0.7\end{array}$ & - & - & $2(9.5 \%)$ & - \\
\hline Ueda [19] & 2013 & $\begin{array}{l}2011- \\
2012\end{array}$ & 50 & 29 & 21 & $\begin{array}{l}152 \pm \\
53\end{array}$ & $63 \pm 62$ & VATS & - & - & - & - & - \\
\hline Nakashima [20] & 2010 & $\begin{array}{l}2000- \\
2009\end{array}$ & 333 & 132 & 201 & - & - & VATS WR & $\begin{array}{l}4.6 \pm \\
2.2\end{array}$ & - & - & $\begin{array}{l}10 \\
(7.5 \%)\end{array}$ & - \\
\hline
\end{tabular}

YOP year of publication, TP Total Patients, NCT No chest tube, CT Chest tube, $M$ male, $F$ female, - Not report, VATS, video-assisted thoracic surgery, LOS length of stay, PN Pneumonia, SE Subcutaneous emphysema, PT Pneumothorax, AT Arrhythmia, OT Operation time, WR wedge resection, OM Operation method, BL Blood loss

Table 3 Summary of articles reporting on chest tube in patients with thoracic surgery

\begin{tabular}{|c|c|c|c|c|c|c|c|c|c|c|c|c|c|}
\hline \multirow[t]{2}{*}{ Author } & \multirow[t]{2}{*}{ YOP } & \multirow{2}{*}{$\begin{array}{l}\text { Study } \\
\text { Period }\end{array}$} & \multirow[t]{2}{*}{$\mathrm{TP}$} & \multirow[t]{2}{*}{$\mathrm{NCT}$} & \multirow[t]{2}{*}{$C T$} & \multicolumn{8}{|c|}{ CT Group } \\
\hline & & & & & & OT & $\begin{array}{l}\mathrm{BL} \\
(\mathrm{mL})\end{array}$ & $\mathrm{OM}$ & LOS & PN & SE & PT & AT \\
\hline Cheng [13] & 2019 & $\begin{array}{l}2014- \\
2018\end{array}$ & 282 & 246 & 36 & $48 \pm 6$ & $3 \pm 0.4$ & VATS & 2 & - & $\begin{array}{l}202 \\
(82.11 \%)\end{array}$ & $2(0.8 \%)$ & - \\
\hline Watanabe [14] & 2017 & $\begin{array}{l}1998- \\
2002\end{array}$ & 93 & 42 & 34 & - & - & VATS WR & $3.6 \pm 1.5$ & 1 (2.9\%) & - & $1(2.9 \%)$ & - \\
\hline Murakami [15] & 2017 & $\begin{array}{l}2012- \\
2014\end{array}$ & 162 & 102 & 60 & - & - & VATS & $\begin{array}{l}12.9 \pm \\
7.8\end{array}$ & $5(8.3 \%)$ & - & - & $\begin{array}{l}4 \\
(6.7 \%)\end{array}$ \\
\hline $\begin{array}{l}\text { Steunenberg } \\
\text { [16] }\end{array}$ & 2017 & $\begin{array}{l}2011- \\
2014\end{array}$ & 49 & 28 & 21 & - & - & VATS WR & 4 & $1(4.7 \%)$ & - & $1(4.7 \%)$ & - \\
\hline Lu [17] & 2016 & $\begin{array}{l}2013- \\
2015\end{array}$ & 89 & 44 & 45 & - & - & VATS WR & $4.1 \pm 0.8$ & - & $24(53.3 \%)$ & $0(0 \%)$ & - \\
\hline Yang [7] & 2016 & $\begin{array}{l}2015- \\
2016\end{array}$ & 60 & 30 & 30 & $79 \pm 32$ & - & $\begin{array}{l}\text { Uniportal VATS } \\
\text { WR }\end{array}$ & $4.4 \pm 1.3$ & - & - & $\begin{array}{l}4 \\
(13.3 \%)\end{array}$ & - \\
\hline Holbek [18] & 2016 & 2015 & 166 & 51 & 0 & - & - & - & - & - & - & - & - \\
\hline Cui [8] & 2016 & $\begin{array}{l}2012- \\
2016\end{array}$ & 173 & 21 & 19 & $39 \pm 12$ & $\begin{array}{l}24.7 \pm \\
12.3\end{array}$ & VATS & $3.9 \pm 2.7$ & $\begin{array}{l}2 \\
(10.5 \%)\end{array}$ & - & - & - \\
\hline Ueda [19] & 2013 & $\begin{array}{l}2011- \\
2012\end{array}$ & 50 & 29 & 21 & $\begin{array}{l}198 \pm \\
78\end{array}$ & $189 \pm 230$ & VATS & - & - & - & - & $\begin{array}{l}1 \\
(4.7 \%)\end{array}$ \\
\hline Nakashima [20] & 2010 & $\begin{array}{l}2000- \\
2009\end{array}$ & 333 & 132 & 201 & - & - & VATS WR & $6.7 \pm 4.4$ & - & - & $8(4.0 \%)$ & - \\
\hline
\end{tabular}

YOP year of publication, TP Total Patients, NCT No chest tube, CT Chest tube, $M$ male, $F$ female, - Not report, VATS video-assisted thoracic surgery, LOS length of stay, PN Pneumonia, SE Subcutaneous emphysema, PT Pneumothorax, AT Arrhythmia, OT Operation time, WR wedge resection, OM Operation method, BL Blood loss 
study, the authors further analyzed the risk factors of UTI and found that indwelling catheter was an independent risk factor for UTI. This result suggests that the insertion of urinary catheter can reduce the occurrence of UTI. It may also be one of the important reasons for not performing catheterization during thoracic surgery.

As seen in our Tables 2 and 3, all the patients without chest tube underwent with thoracoscopic minimally invasive surgery and over half of the operation method is VATS wedge resection. Yang et al [7] reported a retrospective review that patients with lung cancer underwent Uniportal VATS without chest tube after the surgery, which reduced postoperative pain, residual paresthesia, and LOS compared with multiportal VATS. NCT with the promotion of minimally invasive surgery, especially in VATS pulmonary wedge resection is safe for selected patients, compared with traditional conventional thoracotomy, postoperative complications are relatively low. However, we should pay more attention to the results of the NCT in VATS lobectomy in the future. In addition, the incidence of postoperative complications in patients undergoing minimally invasive surgery is still $20 \%$, and postoperative patient mortality due to complications reaches $10 \%$. Therefore, finding the influencing factors of postoperative complications and taking appropriate measures is the key to consolidate the results of surgical treatment. The common postoperative complications in pulmonary surgery includes pneumonia, subcutaneous emphysema, pneumothorax and arrhythmia. As reported in Cheng et al's research, there were 202 asymptomatic subcutaneous emphysema patients, and the asymptomatic subcutaneous emphysema spontaneously resolved within 3 to 7 days [13].

Hospital hospitalization rates have been shown to be the most important direct cost predictor of patient, which accounts for $31-68 \%$ of hospitalization expenses [10, 22]. In Yang et al's report [9], they analyzed the material costs, care costs and specific time associated with indwelling catheters in the NUC and UC groups in detail (including time to place the catheter, time to replace the drainage device, time to observe and care the patient and time to remove the catheter). Material cost for patients in UC group (4811.48 yuan vs. 296.74 yuan, $P=0.045$ ), nursing expenses (7413.32 yuan vs. 457.32 yuan, $P=0.013$ ) and total cost $(12,224.8$ yuan vs. 754.06 yuan, $P=0.000)$ were higher than the NUC group. The total period of care in the UC group was longer than that in the NUC group. Tubeless minimally invasive treatment and ERAS for patients saves the time of urethral catheter placement and the daily care of the postoperative urinary catheterization, which significantly reduces the nurses' workload [23].

\section{Conclusions}

The purpose of the ERAS program is not only to shorten the postoperative LOS, but also to promote the safe recovery of patients. We find that avoiding chest drain and urinary catheter placement after the surgery appears to be safe and beneficial for patients. The implementation of perioperative management measures must be conducted under the guidance of evidence-based medicine to benefit patients. Thoracic surgery without indwelling catheter is not only the embodiment and implementation of the ERAS concept, but also an effective process to improve the patient's perioperative satisfaction and comfort. At the same time, we should pay attention to preoperative evaluation of the patient's medical history and surgical methods to assess whether patients need to input the catheter or not. It is necessary to conduct multi-center clinical research in a number of hospitals across the country to obtain clinical evidence.

\section{Abbreviations \\ ERAS: Enhanced recovery after surgery; LOS: Length of stay; CRBD: Catheter- Related Bladder Discomfort; POUR: Postoperative urinary retention; VATS: Video-assisted thoracic surgery}

\section{Acknowledgements}

We greatly appreciate the assistance of the staff of the Department of Thoracic Surgery, West-China Hospital, Sichuan University, and thank them for their efforts.

\section{Authors' contributions}

CS was involved in drafting the manuscript. GC made contributions to the concepts, acquisition and analysis of the data. CS was involved in acquisition of data and preparing the Tables. GC designed and revised the manuscript. All authors have read and approved the final manuscript.

\section{Funding}

The Science and Technology Project of the Health Planning Committee of Sichuan (No.19PJ242)

Sichuan Province Science and Technology Support Program (No. 2020JDKP0023).

\section{Availability of data and materials}

All data for this study are publicly available and are ready for the public to download at no cost from the official websites of the PubMed, EMBASE,

$\mathrm{CNKI}$ and the Web of Science. There is no need to have the formal permission to use data for this study.

Ethics approval and consent to participate Not applicable.

Consent for publication

All the authors consent to publish the paper.

\section{Competing interests}

The authors declare that they have no competing interests.

Received: 10 February 2020 Accepted: 18 May 2020

Published online: 24 May 2020

\section{References}

1. Holbek BL, Christensen M, Hansen HJ, Kehlet H, Petersen RH. The effects of low suction on digital drainage devices after lobectomy using videoassisted thoracoscopic surgery: a randomized controlled trial. Eur J Cardiothorac Surg. 2019;55(4):673-81.

2. Shen C, Che G. Tubeless minimally invasive treatment: taking a new step in enhanced recovery after surgery (ERAS). Thorac Cancer. 2019;10(11):2067-70.

3. Slim K. Laparoscopy within fast-track or within enhanced recovery after surgery? Ann Surg. 2014;259(2):e24. 
4. Li S, Jiang L, Ang KL, Chen H, Dong Q, Yang $H$, et al. New tubeless videoassisted thoracoscopic surgery for small pulmonary nodules. Eur J Cardiothorac Surg. 2017;51(4):689-93.

5. Lai Y, Wang X, Zhou K, Su J, Che G. The feasibility and safety of no placement of urinary catheter following lung Cancer surgery: a retrospective cohort study with 2,495 cases. J Invest Surg. 2019:1-8.

6. Peng G, Liu M, Luo Q, Chen H, Yin W, Wang W, et al. Spontaneous ventilation anesthesia combined with uniportal and tubeless thoracoscopic lung biopsy in selected patients with interstitial lung diseases. J Thorac Dis. 2017;9(11):4494-501.

7. Yang SM, Wang ML, Hung MH, Hsu HH, Cheng YJ, Chen JS. Tubeless Uniportal thoracoscopic wedge resection for peripheral lung nodules. Ann Thorac Surg. 2017;103(2):462-8.

8. Cui F, Liu J, Li S, Yin W, Xin X, Shao W, et al. Tubeless video-assisted thoracoscopic surgery (VATS) under non-intubated, intravenous anesthesia with spontaneous ventilation and no placement of chest tube postoperatively. J Thorac Dis. 2016;8(8):2226-32.

9. Yang M, Chen J, Che G. Cost-effectiveness analysis of perioperative no indwelling urinary catheter in lung cancer patients with pulmonary lobectomy. Chin J Clin Thorac Cardiovasc Surg. 2016;23(05):421-4.

10. Qiu F, Yang M, Che G. Risk factors of postoperative urinary retention without perioperative urinary catheterization after video-assisted thoracoscopic surgery lobectomy. Chin I Clin Thorac Cardiovasc Surg. 2016; 23(04):328-33.

11. Xu Z, Yang M, Qiu F. Perioperative painless indwelling urethral catheter in lobectomy of lung cancer: a prospective cohort study. Chin J Clin Thorac Cardiovasc Surg. 2016;23(04):323-7.

12. Qiu F, Yang M, Wang W. Clinical effect of postoperative no indwelling urethral catheters after pulmonary lobectomy: a prospective cohort study. Chin J Clin Thorac Cardiovasc Surg. 2015;22(07):634-7.

13. Cheng K, Yuan M, Xu C, Yang G, Liu M. A chest tube may not necessary in children thoracoscopic lobectomy. Medicine. 2019;98(26):e15857.

14. Watanabe A, Watanabe T, Ohsawa H, Mawatari T, Ichimiya Y, Takahashi N, et al. Avoiding chest tube placement after video-assisted thoracoscopic wedge resection of the lung. Eur J Cardiothorac Surg. 2004;25(5):872-6.

15. Murakami J, Ueda K, Tanaka T, Kobayashi T, Kunihiro Y, Hamano K. The validation of a no-drain policy after thoracoscopic major lung resection. Ann Thorac Surg. 2017;104(3):1005-11.

16. Steunenberg BE, Aerts BAC, HGWd G, PJHJ R, Boot CA, Veen EJ. Is it still necessary to leave a chest tube after video-assisted pulmonary wedge resection? Indian J Thorac Cardiovasc Surg. 2017;33(2):132-6.

17. Lu TY, Chen JX, Chen PR, Lin YS, Chen CK, Kao PY, et al. Evaluation of the necessity for chest drain placement following thoracoscopic wedge resection. Surg Today. 2017;47(5):606-10.

18. Holbek BL, Hansen HJ, Kehlet H, Petersen RH. Thoracoscopic pulmonary wedge resection without post-operative chest drain: an observational study. Gen Thorac Cardiovasc Surg. 2016;64(10):612-7.

19. Ueda K, Hayashi M, Tanaka T, Hamano K. Omitting chest tube drainage after thoracoscopic major lung resection. Eur J Cardiothorac Surg. 2013;44(2): 225-9 discussion 229.

20. Nakashima S, Watanabe A, Mishina T, Obama T, Mawatari T, Higami T. Feasibility and safety of postoperative management without chest tube placement after thoracoscopic wedge resection of the lung. Surg Today. 2011:41(6):774-9

21. Wahl TS, Goss LE, Morris MS, Gullick AA, Richman JS, Kennedy GD, et al. Enhanced recovery after surgery (ERAS) eliminates racial disparities in postoperative length of stay after colorectal surgery. Ann Surg. 2018;268(6): 1026-35.

22. Dickinson KJ, Taswell JB, Allen MS, Blackmon SH, Nichols FC, Shen R, et al. Factors influencing length of stay after surgery for benign foregut disease. Eur J Cardio Thorac Surg. 2016;50(1):124-9.

23. Li W, Zheng B, Zhang S, Chen H, Zheng W, Chen C. Feasibility and outcomes of modified enhanced recovery after surgery for nursing management of aged patients undergoing esophagectomy. J Thorac Dis. 2017:9(12):5212-9.

\section{Publisher's Note}

Springer Nature remains neutral with regard to jurisdictional claims in published maps and institutional affiliations.

\section{Ready to submit your research? Choose BMC and benefit from}

- fast, convenient online submission

- thorough peer review by experienced researchers in your field

- rapid publication on acceptance

- support for research data, including large and complex data types

- gold Open Access which fosters wider collaboration and increased citations

- maximum visibility for your research: over $100 \mathrm{M}$ website views per year

At BMC, research is always in progress.

Learn more biomedcentral.com/submissions 